Summer 8-16-2021

\title{
How the Past of Outsourcing and Offshoring is the Future of Post- Pandemic Remote Work: A Typology, a Model, and a Review*
}

\author{
Peter Norlander \\ Loyola University Chicago, pnorlander@luc.edu \\ Chris Erickson \\ UCLA Anderson, chris.erickson@anderson.ucla.edu
}

Follow this and additional works at: https://ecommons.luc.edu/business_facpubs

Part of the Human Resources Management Commons, Labor Economics Commons, and the Labor Relations Commons

Author Manuscript

This is a pre-publication author manuscript of the final, published article.

\section{Recommended Citation}

Norlander, Peter and Erickson, Chris. How the Past of Outsourcing and Offshoring is the Future of PostPandemic Remote Work: A Typology, a Model, and a Review*. How the Past of Outsourcing and Offshoring is the Future of Post-Pandemic Remote Work: A Typology, a Model, and a Review*, , : , 2021. Retrieved from Loyola eCommons, School of Business: Faculty Publications and Other Works,

This Working Paper is brought to you for free and open access by the Faculty Publications and Other Works by Department at Loyola eCommons. It has been accepted for inclusion in School of Business: Faculty Publications and Other Works by an authorized administrator of Loyola eCommons. For more information, please contact ecommons@luc.edu.

\section{(c) $\odot \ominus$}

This work is licensed under a Creative Commons Attribution-Noncommercial-No Derivative Works 3.0 License. 
How the Past of Outsourcing and Offshoring is the Future of Post-Pandemic Remote Work: A Typology, a Model, and a Review*

\author{
Christopher Erickson ${ }^{1}$ \\ Peter Norlander ${ }^{2}$ \\ ${ }^{1}$ UCLA Anderson School of Management, UCLA, USA. \\ ${ }^{2}$ Quinlan School of Business, Loyola University Chicago; USA \\ E-mail: chris.erickson@anderson.ucla.edu; pnorlander@luc.edu
}

August 16, 2021

\begin{abstract}
Information and communication technology (ICT) challenges traditional assumptions about the capacity to manage workers beyond organizational and physical boundaries. A typology connects a variety of non-traditional work organizations made possible by ICT, including offshoring, outsourcing, remote work, virtual companies, and platforms. A model illustrates how new technology serves as a proximate cause for a revision of social contracts between capital, labor and government reached through bargaining, and how external shocks such as the COVID-19 pandemic, the institutional environment, and limitations in practice influence how technology changes the organization of work. An historical case illustrates the general features of the model, and a review of the outsourcing and offshoring literature provides instructive examples of how features of the model will potentially influence the future of post-pandemic remote work.
\end{abstract}

Keywords: information and communication technology, institutional change, offshoring, outsourcing, remote work.

JEL Codes: J60, J50, J44, J22, O30, R12

\footnotetext{
* The authors thank and acknowledge helpful feedback from Sanford M. Jacoby, Sarosh Kuruvilla, and participants at the ILO 7th Conference of the Regulating for Decent Work.
} 
Emerging technologies and non-traditional work arrangements have led many to prophesize radical changes for the "future of work," but in the last quarter century, the transformation of work organization away from the traditional factory or office has generally not shown up in the statistics on workplace organization. Despite claims that the growth of contingent work on platforms represented a dramatic change in how Americans work, contingent work remained stable between 2003 and 2017 in the U.S. (BLS 2018). During the COVID-19 pandemic, the peak availability of remote work arrangements for pay in the United States was 38\% in May 2020; a year later, in May 2021, this declined to $18 \%$ (BLS 2021). For decades, information and communication technology enabled a wide array of jobs to be done remotely, and yet: only $10 \%$ worked from home at least one day a week in 2017-2018, compared to 15\% in May 2004, which was unchanged from May 2001, compared to 17\% that worked from home at any time in May 1997 (BLS 1998, 2002, 2005, 2019). The waxing and waning of remote work during the pandemic, and the stability of traditional workplace organization prior to COVID-19, beg the question of how exactly technology is transforming the organization of work.

The evolution of workplace institutions, and the role of technology in transformations of work, has attracted a large literature across the social sciences. We develop an explanation of technology-linked changes in work organization rooted in theories of institutional change, bargaining, monitoring, and social contracts. Specifically, we offer a new typology of technologically-enabled working arrangements, encompassing the traditional workplace, offshoring, outsourcing, remote work, contingent work on platforms, and virtual companies. A model focused on explaining the adoption of remote work illustrates how factors including power relations, external shocks, limitations in practice and bargaining processes influence the 
course of the adoption of alternative work arrangements in a given context in response to technological change.

While technology can create the potential for new forms of work organization, we view work organization itself as fundamentally governed by social contracts that settle who is to do what and when, how they are to be monitored and paid, and who is in charge. When a new technology emerges, growing dissatisfaction with the status quo and external shocks (such as pandemics) lead to new capital-labor-government negotiations over the existing organization of work. The institutional environment, including the relative power of workers and managers, influences the bargaining over the future social contract. Limitations of technology in practice, such as employee and managerial preferences and capabilities, shape the resulting arrangement. The key outcome is a context-specific, and largely implicit, social contract that settles the rights and obligations of workers, managers, and organizations into a stable equilibrium.

We introduce a typology of alternatives to the traditional workplace influenced by technological possibility and a theoretical model illustrating how technologies are incorporated into work arrangements. Now that we know from the pandemic what can be done at a distance, we review of earlier literature on offshoring and outsourcing, which gives clues as to the extent to which work will be done at a distance post-pandemic.

\section{A Typology of Non-Traditional Work Environments}

Over decades, information and communications technologies (ICT) have expanded traditional organizational and physical boundaries, making offshoring, outsourcing, and remote work possible to a greater extent than before. The adoption of the traditional factory or office itself may have arisen from a view that efficiency and productivity are best achieved through observation, which can increase both learning and control (Bernstein 2016). Crouch (2018) 
observes that ICT "intensified control that facilitates the current trend to self-employment," and it also allows for easy communication across physical distances more generally. In outsourcing, a task is done by another organization. With offshoring, a task can be done offshore. With remote work, a task can be done off premises. In combination, the configurations of offshoring, outsourcing and remote work form a typology that captures many non-traditional work arrangements.

In Figure 1, the "traditional workplace" is one where the work is not outsourced, offshored, or done remotely. In other words, a workplace where the workers are together in the same place working as employees for the same organization, as in a factory or an office building. "Onsite outsourcing" is a workplace where the task is done on-site by another organization, for example building cleaning contractors (Erickson et al. 2002). "Offshore outsourcing" is work done by another organization offshore, but not remotely; for example, the software campuses of IT contractors such as Infosys in India. "Captive onsite offshoring" is work done offshore within an organization, but not remotely, e.g., when an organization has sites in different countries.

Figure 1. The Four Quadrants of Offshoring and Outsourcing 


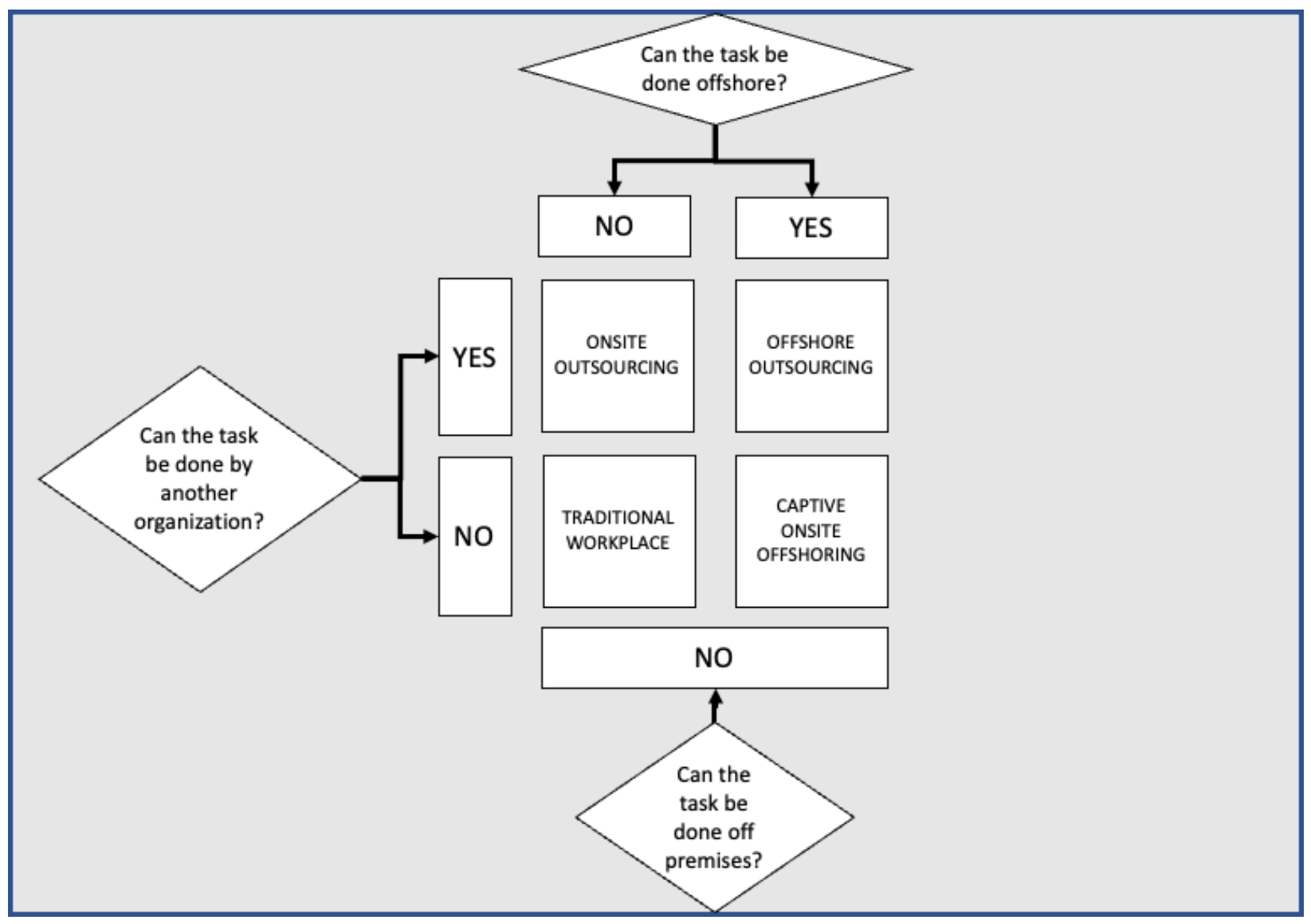

As in Figure 1, previous research contrasted outsourcing (within organization / outsourced) and offshoring (home country / foreign country) using a two-by-two table to conceptualize the globalization of services work (Eden 2005; Dossani and Kenney 2007; Contractor et al. 2010). With new technology, organizations faced three new choices or "quadrants" of outsourcing and offshoring, and could adopt a non-traditional structure involving offshoring, outsourcing, or both. The four-quadrant framework recognized that decisions to outsource and offshore were linked with one another and with business strategy (Mudambi and Venzin 2010). Logically, they are similar: outsourcing involves the disaggregation of work once entirely inside the organization, and offshoring work into global value chains opens the door to comparative advantages (ibid). Strategic decisions to outsource could be undertaken simultaneously with 
decisions to offshore (Rugman and Verbeke 2001), and logically should be (Contractor et al. 2010).

As depicted in Figure 1, a tacit assumption about remote work and its connection to offshoring and outsourcing was that while technology enabled work to be done at a distance and outside of the organization, it would still be done in an office or factory. Workplace studies long highlighted the important role of teamwork, or social/peer control (Ouchi 1980), that was embedded within a physical space. Remote work was more often discussed in the context of flexible work arrangements and work-life balance. Still, remote work and offshoring are conceptually linked. For example, Blinder (2006) identified offshorable jobs as those that could be done at a distance while keeping quality intact, with a methodology similar to the one used during COVID to identify occupations that are candidates for remote work (Dingel and Neiman 2020). Remote work was not seen as part of strategic employment relations choices, and organizations and scholars largely did not pair the remote work decision with the offshoring and outsourcing decisions.

\section{Emerging alternative work environments}

Figure 2 shifts the typology from four quadrants to eight quadrants by adding a third (remote or off-premises) dimension. The four new quadrants of remote work are described in more detail below, moving clockwise in the shaded part of the diagram from the bottom left. In this typology, configurations regarding remote work, offshoring, and outsourcing are determined by choices regarding new technological possibilities. ${ }^{1}$

\footnotetext{
${ }^{1}$ Note that a single complex organization may operate under different modes: for example, a firm with a traditional workplace for U.S. employees, such as Nike, may have outsourced and offshored production. A firm that permitted a remote workplace an executive and managerial elite, such as Best Buy under its "Results Only Work Environment" policy, maintained a traditional workplace for its stores.
} 
Remote workplace

A "remote workplace" is where tasks are done offsite, but within an organization and country. The most salient example here is much of the work that has occurred from home by employees during the pandemic. In the U.S., a relevant feature of remote workplaces prior to the pandemic is that they have been largely reserved for an elite: only 4 percent of workers in the lowest earning quartile worked at home exclusively for a day in $2017-2018$, compared to $35 \%$ of workers in the top quartile (BLS 2019).

\section{Remote outsourcing}

"Remote outsourcing" occurs when tasks are done by employees working remotely and offsite that are managed by another organization. An example could be an outsourced call center that hires call center operators domestically and remotely. A growing number of service providers enable their employees to work remotely, providing outsourced customer support, HR, finance, and other business services to client organizations from their homes via e-mail, phone, and videoconferencing. An emerging post-pandemic example is the growth of tele-therapy firms such as Alma Health that connect a network of licensed therapy providers to patients across the U.S. Companies that exist as standalone platforms are not the only users of this organizational model: Federal Express has long used technology to supervise its U.S. network of independent contractors.

\section{Globally Distributed Platform Work}

At the extreme opposite of the traditional workplace is "globally distributed platform work" where the work is outsourced, offshored, and done remotely (outside of a physical plant such as a factory, office, or restaurant). Examples here include situations where organizations connect with 
non-employee workers in far off places, through platforms such as Uber ${ }^{2}$, Gigster, Upwork, etc. Brick and mortar companies also augment their workforce with globally distributed platform workers: Amazon's Mechanical Turk, and now its algorithmically supervised global delivery network of independent contractors, adopt a similar outsourced, remote, global platform model. In essence, globally distributed platform work involves electronically mediated management, with a network of independent contractors who work remotely from anywhere in the world.

\section{Virtual companies}

Finally, "virtual companies" refer to work done by employees within an organization who could be anywhere except an office - in locations that are both off-site and off-shore. In other words, headquarter-less, office-less companies with employees spread around the globe.

Prominent examples here include DuckDuckGo, GitHub and Mozilla (Stillman 2016).

Figure 2. A Typology of Non-Traditional Work Environments

\footnotetext{
${ }^{2}$ While Uber drivers provide in-person services, their work is done by an independent contractor, in almost any country, who is remotely supervised, and never meets with a boss, e.g. at a taxi company.
} 


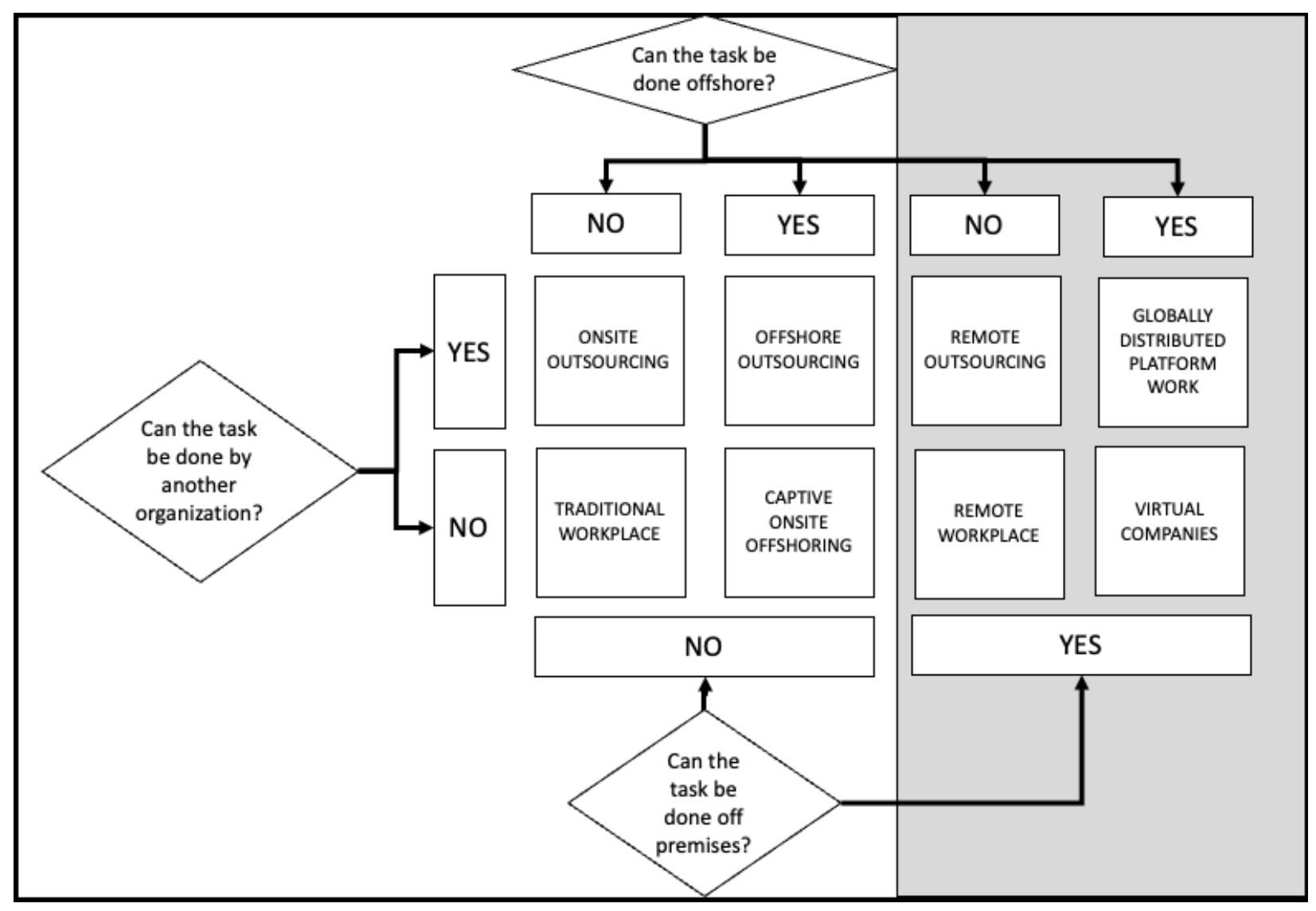

\section{Information Communication Technology and Its Impact on Work}

The role of ICT in pushing trends of outsourcing, offshoring, virtual companies, platform work, and remote work has been argued in piecemeal and in broad strokes. Technology has increased the ability to supervise and manage across geographical and organizational boundaries, and has simultaneously increased firms' ability to intensify monitoring (and raise productivity) in a traditional workplace (Ranganathan and Benson 2020). The typology above describes eight alternative work environments as different responses to a set of possibilities raised by technology, offering a simple framework. What then explains how a particular non-traditional outcome emerges? The following section addresses this question with a theoretical model, a historical parallel, and a description of the current situation with respect to remote work. 


\section{A Model of How Technology Influences the Organization of Work}

Similar to Barley (2020), we posit that the technology transforms work through changing roles and relationships. Our approach also follows Streeck's (2009) contention that changes in workplace organization are not a part of "historical progress," a "collective and consensual quest for higher levels of efficiency" or an effort to "[economize] on transaction costs" as a rational choice. Models of institutional change have emphasized punctuated equilibrium, notions of gradual change, and "layering," or the addition of new elements on to old institutions (Thelen 2004). Specifically, such layering often involves the "partial renegotiation of some elements of a given set of institutions" (Thelen 2003). Similar to Thelen, we do not dismiss the potential for radical, sudden change, but also allow for the possibility of transformation through incremental change involving the renegotiation of aspects of institutions, or social contracts, in response to technological innovation, which can leave many existing features unchanged (Thelen 2009). Thus, workplace institutions evolve in response to external shocks such as technological innovations, themselves sometimes sudden or discontinuous, but in either a punctuated or layered manner depending on the circumstances. The new equilibrium that emerges from a bargaining process between capital, labor and government constitutes a revised social contract.

\section{A Brief Description of the Model}

Figure 3A illustrates how technology leads to changes in the organization of work through broadly defined (and sometimes implicit) bargaining between capital, labor, and government. External shocks, limitations in practice, and the institutional environment influence how bargaining processes alter the organization of work as part of a revised social contract, in response to technological changes. 
Figure $3 A$. A Model of the Impact of Technological Changes on the Organization of Work

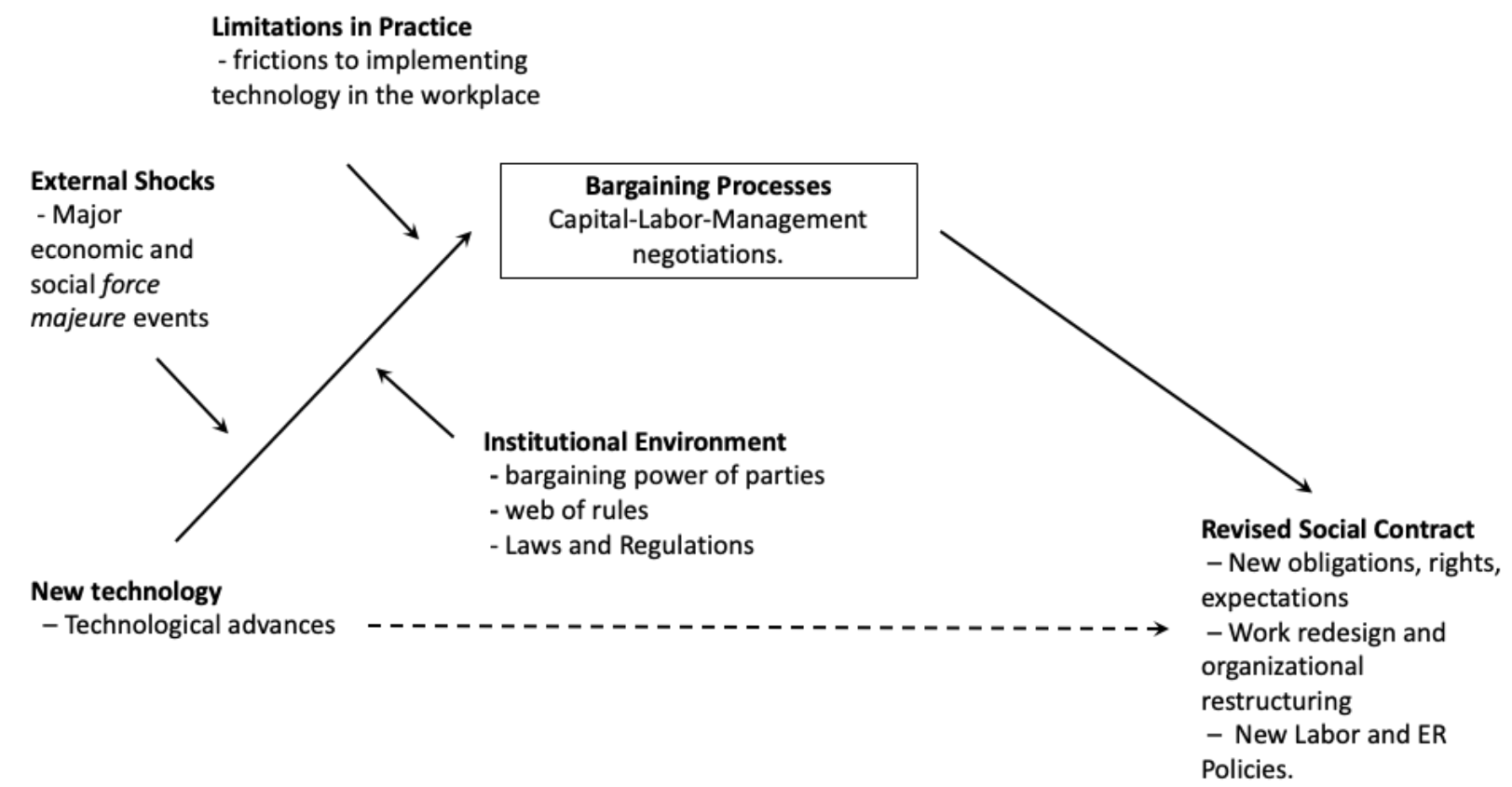

A process of institutional change through bargaining

In between a new technology and a new equilibrium of work organization, growing dissatisfaction by one or more parties and external shocks in the form of major economic or social force majeure events, such as depressions, wars, and pandemics, lead to breaks in existing practices and bargaining over what comes next. Institutions of industrial relations such as collective bargaining that include formal worker representation, union contracts and codetermination are part of the institutional environment, but bargaining is carried out within a broader institutional environment or bargaining system (Doellgast and Benassi 2020). In the current era of often indirect employment relationships, bargaining can also take the form of "network bargaining" in which labor can wield symbolic and associational power outside of hierarchically organized labor actions (Anner, Fischer-Daly, and Maffie 2021). Change at the level of the work process engages individual workers and managers and owners in negotiated modifications to the routine scripts, networked processes, roles and relationships (Barley 2020). 
Large-scale, societal negotiations over new laws and institutional practices (as in California's proposition 22 to create separate employment regulations for gig work), take place as interested parties seek to establish new workplace practices. Thus, capital-labor-government negotiations ("bargaining processes" broadly defined, at the center of the figure) determine a new social contract.

Factors that influence the bargaining process

Elements of the institutional environment such as existing laws, customs and regulations and the bargaining power of workers and managers influence the negotiations. The environment is unpredictable. For example, bargaining power itself is dynamically shaped by new developments in the environment (Bacharach and Lawler 1980). The institutional environment is "specified with respect to time and place," is "action-based," and focused on a "conflictual interplay between the individual pursuit of economic advantage and collective political efforts at restoring and protecting social stability" (Streeck 2009).

Limitations in practice such as worker and manager resistance to technological change and inherent impediments to the adoption of technology such as the role of tacit knowledge influence the negotiations as well. New technologies often have pre-requisites for success, such as requiring a trained workforce. The role of knowledge-sharing organizations and social networks in the transmission of new workplace practices highlights the cultural embeddedness of the adoption of new technology at work (Erickson and Jacoby 2003). Status quo arrangements have staying power; adoption is often path dependent upon prior choices, and upon employee and management costs and fears in adopting technology. 
As depicted at the bottom right of Figure 3A, the outcome of the bargaining process is labeled a "revised social contract" that specifies the obligations of each party in an employment relationship, often implicitly, and is a means of reducing conflict. The social contract is documented in national laws, employee handbooks, and contracts, and is a complex "web of rules" that are commonly unspoken assumptions and tacit agreements. It involves implicit understandings in a workplace of the content of the rules, who does what, what is owed, what the rights and obligations of parties such as employees and managers are, who has what authority under the rules, and how new rules can be established (Lipsky, Seeber, and Fincher 2003). This could also be called "changes in the organization of work," "the future of work" or the "new equilibrium." Social contracts exist at multiple levels of analysis (nations or organizations, e.g.).

Once a new social contract is reached, rules and lines of authority are clear. Still, the resulting arrangement is not an endpoint or logical outcome of a new technology, but an everevolving institutionalized social order (Streeck 2009). New technology and external shocks can disrupt the operation of the existing workplace social contract, but only renegotiation in some form can provide a stable revised social contract.

\section{Historical Metaphor: The New Deal IR System}

A metaphor for the potential transformation of the workplace from communication technology and the pandemic is the development of the "New Deal Industrial Relations System" in the 1930s and 1940s in response to Taylorism/Fordism and the division of labor in the modern industrial factory. Managerial authority and control in the first half of the 20th Century was paramount (Jacoby 2004). The adoption of the Fordist/Taylorist division of labor increased dissatisfaction from workers, and frequent conflict, sometimes violent, drew scrutiny from the government and ultimately contributed to the overhaul of the existing social contract. Figure 3B 
presents the simple model above using this context. In a bargaining process that took place between roughly 1932 and 1947, the outcome was a new social contract that provided a stable structure of work organization for the following decades.

The Taylorist/Fordist division of labor and factory technology enabled a new mode of production, a movement away from the craft model of production and toward mass production of ever more standardized products at an ever lower per-unit cost with ever more deskilled labor (Piore and Sabel 1986). Taylorism/Fordism promised management increased productivity, but also met with unprecedented worker resistance. The actual organization of work and employment relations that resulted occurred through capital-labor-government negotiations, influenced by the existing forms of capitalism and the impacts of force majeure events including the Great Depression and the world wars. The wars may be thought of as a parallel to the pandemic - extreme events that showed what could be done by adopting factory and Taylorist/Fordist methods, but not what would emerge after the crises.

In negotiations such as the "Treaty of Detroit," a primary concern of labor's was to limit managerial discretion over terms and conditions of employment, including job duties. A primary concern of government and management was to reduce conflict and stabilize production. Tripartite negotiations developed consensus around grievance and alternative dispute resolution procedures that became widespread (Lipsky et al. 2003). The societally negotiated outcome was the U.S. style "job control unionism" that attached wages to jobs, and allocated jobs and layoff/recall primarily via seniority, thus eliminating a great amount of managerial discretion in determining both wages and job allocations (for example, Katz 1985). Though labor was powerful enough for a time to threaten managerial prerogatives in a wide array of areas, unions 
challenged managers on "where workers were to do work" and "what they're to do," but did not fundamentally disturb the organization of firms (Chamberlain 1951, 1963).

Wages and labor allocation could have been determined by many possible factors, such as skill or competencies or pure seniority or managerial discretion, but instead the "job" became the organizing concept for wage bargaining, and seniority became the rule for assignment to jobs, layoffs, and recall. In the non-union workplace, bureaucratic HR operations curtailed managerial authority and implemented grievance procedures, standard pay scales, job descriptions, seniority, and other union-like practices (Jacoby 2004).

The political environment drove this societal negotiation and the outcome beyond any purely technological or efficiency logic. But there were also alternative models developed under different circumstances in other parts of the industrialized world (regarding Japanese models, see, for example, Dore 1973; Cole 1979). In other words, the technological change was not purely deterministic, but was rather reflected through the lens of external shocks, limitations in practice, and the institutional environment for the determination of the revised social contract and the new organization of the workplace in the New Deal IR System. Or, in Barley's (2020) terms, the use of technology was socially constructed but influenced by physical contexts. Figure 3B. Taylorism/Fordism \& The New Deal Industrial Relations System 


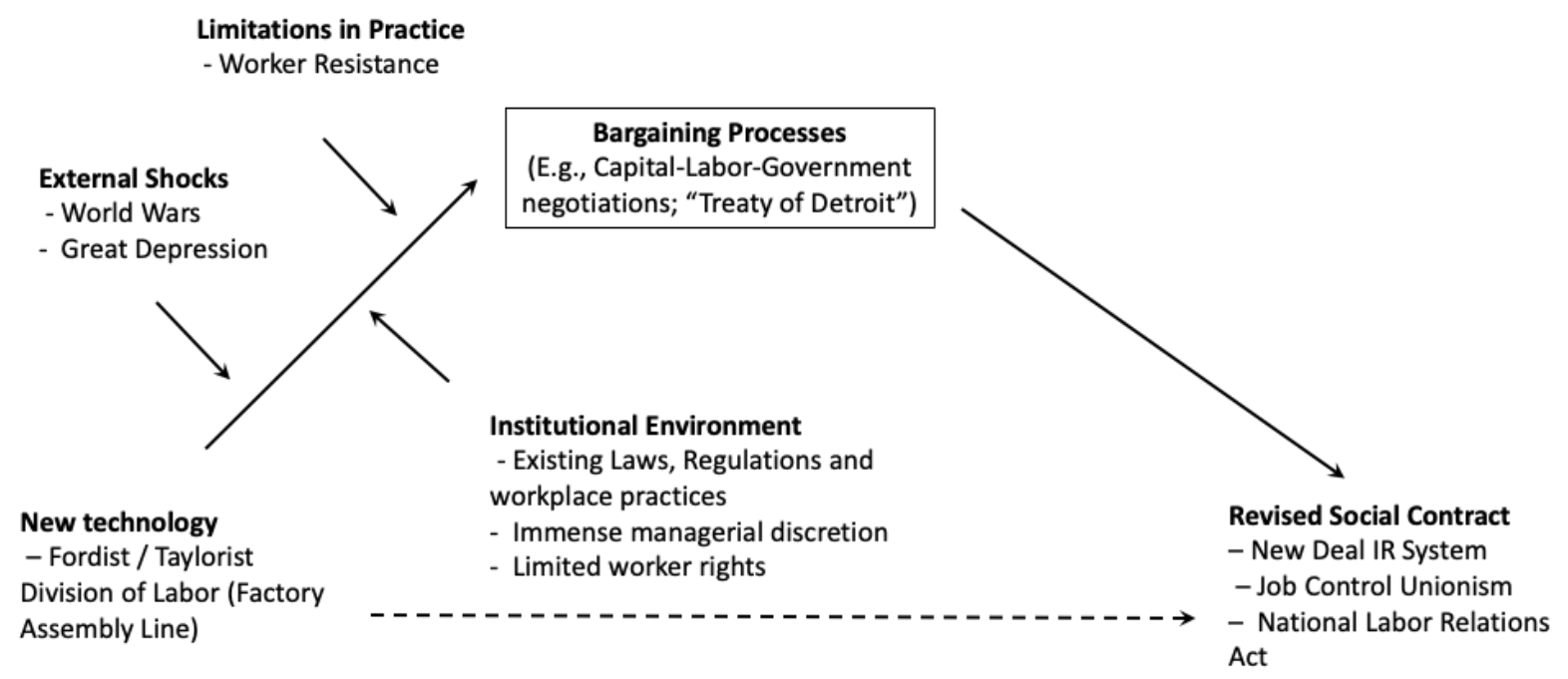

\section{The current situation}

In the current situation, the technological change involves the advance in remote communications potential and the impetus for change is varied dissatisfaction with the status quo: companies seeking lower cost labor and facing new global competition; workers seeking greater flexibility in working arrangements; and the external shock of the pandemic. With the arrival of ICT, and in particular algorithmic management, the ownership, fairness, transparency, privacy, and legal protections for workers have become contested terrain (Kellogg, Valentine, and Christin 2020). Figure 3C summarizes the model as applied to outsourcing, offshoring, and remote work environments.

The purely technological or efficiency-based logic might suggest that new technology would lead to a wholesale movement toward outsourced, offshore, and remote work, but events such as the pandemic, and institutional and societal influences shape the negotiations among capital, 
labor and government that determine social contracts at work, and will determine how work itself will be organized once the immediate crisis ends.

The process is taking place through negotiations happening now, including the development of laws regarding gig work at a societal level, and the development of new procedures at an organizational level. A revised social contract must be negotiated: although technology enables remote work, a new company policy, for example, establishes the nature of remote work after the COVID-19 pandemic, and spells out the rights and obligations for workers and managers. A collective bargaining agreement could cement a deal where unions exist. A remote employee who is called back to the office can challenge the employer's offered working conditions. Employers can revise their employment offers if worker preferences are changing and labor markets are tight.

Figure 3C. A Model of the Impact of Technological Changes on the Organization of Work: Communication Technology \& Outsourcing/Offshoring/Remote Work

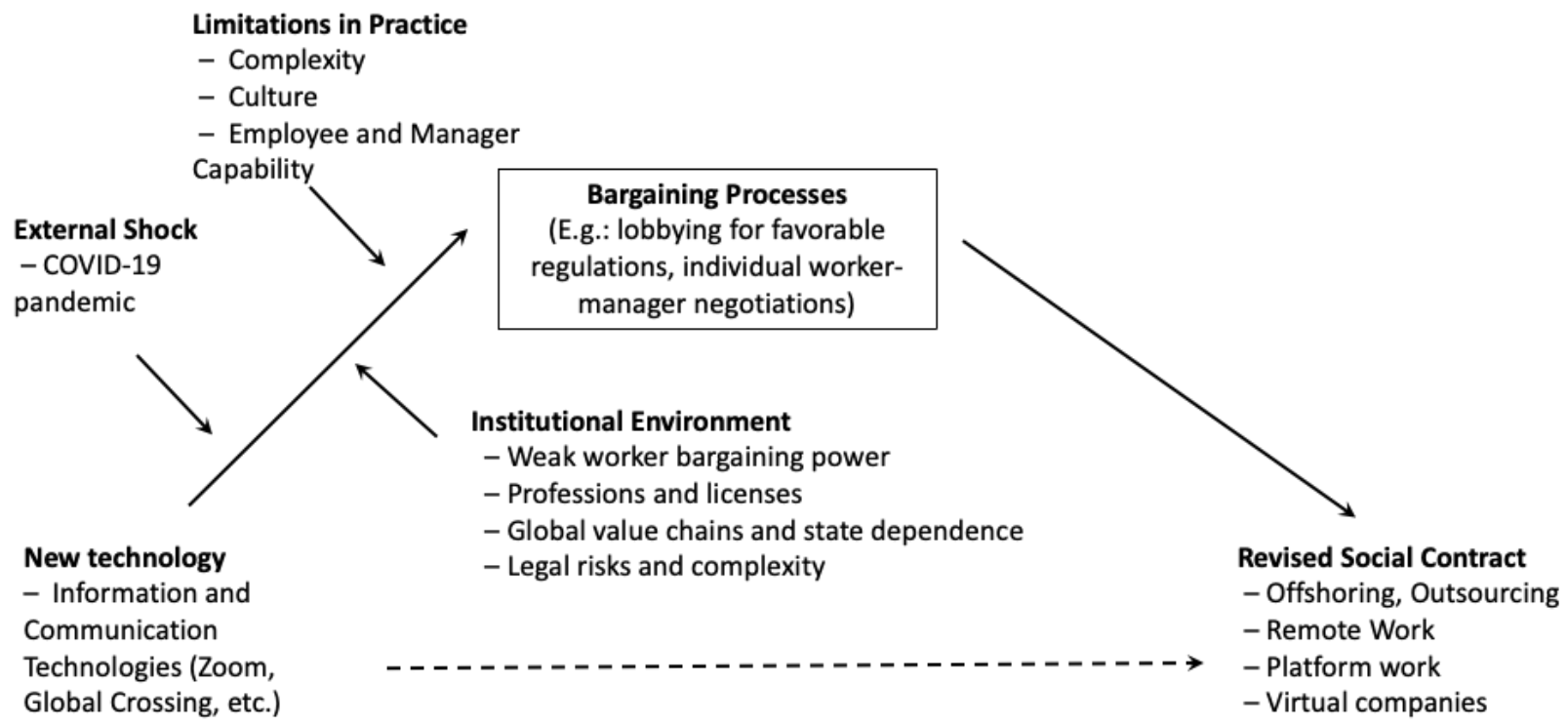




\section{Lessons from offshoring and outsourcing: Bargaining over the Future of Work}

Fear of a deadly pandemic led society - beginning with calls from the public and including government mandates - to sanction widespread work from home in March 2020 using existing technologies. The force majeure broke existing arrangements and understandings of the necessity of on-premises work, but what will the post-pandemic workplace look like?

In the historical example above, the path from the division of labor to job control unionism was influenced by a set of institutional configurations that is far different from the relevant set of institutions shaping the potential new work from home equilibrium. In this section, we describe the literature on the institutional environment and limitations in practice surrounding the more recent examples of outsourcing and offshoring, and speculate on that basis about the potential lasting changes in the organization of work enabled by remote communication technology. The application to remote work draws from reviews of the literature on offshoring (Mihalache and Mihalache 2016; Schmeisser 2013) outsourcing (Hätönen and Eriksson 2009) and offshore outsourcing (Javalgi, Dixit, and Scherer 2009; Norlander, Jukic, Varma, and Nestorov 2015).

\section{The institutional environment}

Outsourcing and offshoring became prominent in the 1990s and early 2000s, at a time of weakness for U.S. labor, when monopsony power was growing and worker power was ebbing (Erickson and Mitchell 2007; Stansbury and Summers 2020). Outsourcing allows firms with buyer power in product markets to press suppliers to lower wages (Dube and Kaplan 2010; Wilmers 2018). Offshoring allows an influx of new workers who can compete with incumbent workers, benefitting consumers, employers, and owners of capital, at the expense of incumbent employees attached to a specific labor market (Bound, Khanna, and Morales 2018). Growing 
firm power enables further work reorganization and taskification of jobs globally (Katz and Darbishire 2018). Platforms like Uber enable contingent workers anywhere to log on and choose their own hours, but with increased managerial control over these contractors compared to incumbent, domestic operators (Rosenblat 2018; Norlander et al. 2021).

Lahiri and Kedia (2011) find that offshore outsourcing emerges through organizational imperatives and institutional features of the environment, and Lewin and Volberda (2011) emphasize the idiosyncratic co-evolution of offshore outsourcing based on management intention, knowledge, and institutional forces. As discussed below, the specific elements and actors in the institutional environment offer clues about the nature of remote work postpandemic.

\section{Professions and licenses}

Powerful actors such as professional associations can lobby the state and control who may lawfully practice an occupation (Freidson 1974). Such organizations retain control over how an occupation is practiced, influence or control outsourcing and offshoring decisions, and can often raise strong barriers to changing organizational structure or work process ( $\mathrm{Yu}$ and Levy 2010). With ICT, new national and international trade and professional associations also emerged as powerful lobbying actors seeking to influence state regulation in favor of offshoring (Kshetri and Dholakia 2009).

In the case of medical services such as reading radiology exam reports, much of the work can be done anywhere. However, Medicare pays only for services performed in the U.S. Outsourcing is permitted through "nighthawk" services that operate at an efficiency of scale, providing remote locations and night and weekend services as needed. However, under licensing requirements, a local radiologist in state must still review the "nighthawk" service reports. 
Attempts to offshore the work of nighthawk services to India were largely unsuccessful, despite very high wages and seemingly rote work (Yu et al. 2010). Teletherapy provides another example of the influence of licensing. States limit the practice of therapy to licensed therapists within the state, the absence of national licensing limits the scope for remote work, and new systems and team structures must be instituted to increase reach and uptake of teletherapy (Taylor, Fitzsimmons-Craft, and Graham 2020).

While remote outsourcing may be possible under existing licensing regimes during the pandemic, the future of remote tele-therapy, for example, is uncertain. A hypothesis that emerges is that work from home adoption will vary with the extent of licensing requirements. While institutions can change and actors lobby for favorable regulation, a main function of licensure is to restrict the supply of labor to those with professional competence. For remote work to be adopted in settings such as teletherapy, evaluation and ensuring quality in a remote licensing regime will likely require new laws and professional procedures and policies, i.e., a renegotiation of social contracts.

\section{Global value chains and state dependence}

A catalyst for offshoring was a global "race for talent," and associated fear that organizations would be threatened by the emergence of new, lower cost competitors from abroad if they did not offshore and adopt more global hiring practices (Lewin, Massini, and Peeters 2009). Organizations needed not only talent, but flexibility, and outsourcing was seen as necessary to compete. Beyond national regulations, multinational and other organizations' practices are influenced by both the home country institutions and labor relations practices of the buyers in their supply chains (Lakhani, Kuruvilla, and Avgar 2013). With increasingly complex 
global supply chains for services and manufacturing products, workplace policies often spread through the actions of leading firms in the supply chain.

The government has power as a large buyer to set working conditions, and in the U.S., the government uses this power to require contractors to pay prevailing wages, and in recent years and some cases, to source locally. The U.S. government under different administrations has given the "green light" or the "red light" to organizations to engage in outsourcing and offshoring. Exemptions under Republican administrations, for example, lift requirements that outsourced subcontractors be paid the prevailing wage. Under the Trump administration, an executive order promoted stricter enforcement of existing "Buy American" laws with an intention to limit offshoring. The more dependent an organization is on the government, the more responsive it is to government mandates (Salancik 1979). As a large direct employer as well, the government is a highly visible actor and by its own behavior, has power to set benchmarks for employment policies.

We hypothesize that the extent of dependence on the government, as well as the soft influence of government and other lead firm HR and labor practices as a role model for "best practices" will shape bargaining over working from home.

\section{Legal risks and complexity}

Offshoring, outsourcing, and remote work pose different risks from the traditional work environment and a variety of legal considerations shape decisions to offshore or outsource. Intellectual property rights protections in the home country and in the supplier country influence offshoring decisions (Kshetri 2007; Martínez-Noya and García-Canal 2011, 2018). The strictness of privacy laws is negatively related to the propensity of offshoring (Kshetri 2007). Contract 
enforceability in different countries also moderates the potential for offshoring (Antràs and Helpman 2008).

Outsourcing as an employment relations strategy is often intended to reduce risk and financial liabilities related to hiring employees or directly paying independent contractors. The IT industry turned to outsourcing firms to act as employers of record following a court decision in Vizcaino v. Microsoft that reigned in employers' second-class treatment of flexible, nontraditional independent contractors. Subcontracting with another firm that employed these temporary workers made it lawful for leading IT companies to have a flexible workforce paid less than incumbent employees (Barley and Kunda 2011).

For remote work, complex issues of protections for workers with disabilities, state and local taxation, and workers' compensation arise. Managing legal complexity is difficult and provides a substantial advantage to large organizations. Outsourcing and offshoring deals prioritized "large" players; small and medium organizations largely did not have the scale or sophistication to "go global" or outsource effectively (Tambe and Hitt 2012a, 2012b). We hypothesize that work at large organizations, and tasks involving fewer risks, are more likely to be done remotely.

\section{Limitations in practice}

Outsourcing and offshoring are limited by the role of tacit knowledge, and the nonroutine nature of certain tasks that limit their ability to be offshored or automated (Yu et al. 2010; Levy and Murnane 2004). For outsourcing and offshoring to succeed, work practices must change to facilitate the transfer of formerly implicit knowledge (Leonardi and Bailey 2008). While wages may be lower in offshore settings, productivity and quality may also be lower and for many services, productivity and quality are critical. Offshoring location depends on many 
non-wage factors, including common language between countries, greater investment in information and communication technology, decreased political risk, and more highly educated workers (Contractor and Mudambi 2008). When tasks involve higher levels of skill, organizations may prefer near-shoring to offshoring to a distant location (Hahn, Bunyaratavej, and Doh 2011). Long before offshoring emerged as an option, U.S. companies sought (and continue to seek) to relocate operations to lower cost parts of the country to economize on cost (Cowie 1999).

Cultural compatibility between host and supplier country influences offshoring (Kshetri 2007). Trade in services is more likely to occur between countries with higher institutional quality and greater cultural similarity, especially when tasks are non-routine, complex, and interaction is required (Bunyaratavej, Hahn, and Doh 2007; Liu, Feils, and Scholnick 2011). While cultural similarity can proxy for many different things, trust (Leamer and Storper 2014), and ethnic ties (Saxenian 2007; Zaheer, Lamin, and Subramani 2009) influence offshoring decisions.

Scholars also emphasize the productivity gains from physical co-location and proximity of workers. While offshore outsourcing developed, the offshore work environments were traditional work environments, but in a different country, concepts such as the "software factory" were developed to exploit the productivity benefits of physical proximity (Cusumano 1991).

Complex systems are involved. Using tele-therapy as an example, there are concerns with privacy, safety, training and supervision of therapists, and payment to be addressed, and new team structures proposed (Taylor et al. 2020). With a thicket of complexities and regulations, the scale needed to permit the outsourcing and development of a platform for the delivery of such tele-therapy services may be difficult to reach. 
Heterogeneity in business strategies also shape the ability to move work. Choice of offshoring location depends upon firm motivation for offshoring (knowledge-seeking vs. lowcost) (Martínez-Noya, García-Canal, and Guillen 2012). Offshore outsourcing organizations' global recruitment is associated with cost-reduction strategy, while universities and organizations in other industries recruitment is associated with increased investment in research (Norlander and Varma 2019).

In practice, there are many limitations to the ability of a job to be done from home, including worker characteristics. For example, workers ages 25-54 are more likely to work remotely than younger or older workers, reflecting possible different preferences or productivity levels while working from home (Dey et al. 2020). Managerial resistance and skill matter: a central concern when allowing work to be done remotely is managerial control (Medcof 2001). In offshore outsourcing, middle management is intensively involved in both supplier and lead firms, being the "glue" by managing virtual and in-person teams in each location and coordinating work in both places (Wilcocks and Griffiths 2010).

Inside an organization, flexible work arrangements often require greater planning and structure, including standardizing work (Briscoe 2007). A study of the Belgian public sector finds that predictability and bureaucracy reinforce the use of telework, as do managerial and employee skill (Taskin and Edwards 2007). Many US organizations with flexible work arrangements before COVID had policies that permitted managerial discretion to determine whether a particular employee could work from home, rather than basing decisions on need or through a process (Kelly and Kalev 2006). Such "formalized discretion" requiring individualized bargaining between employee and manager is closely related to the inequality and low utilization of work from home. 
A key conceptual shift for managers is to shift from a focus on time to a focus on results (Cascio 2000). Trust must be established between worker and manager, and managers are often lacking knowledge of how to plan and organize activities or supervise remote workers (Green and Roberts 2010). Hypotheses that emerge are that educational requirements as well as organizational, industry, workforce and managerial characteristics will influence the adoption of the new technology.

Finally, persistent national differences in industrial relations shape workplace outcomes (Thelen 2004; Jacoby 2005; Katz and Darbishire 2018). Remote work is no different. Nordic countries led in work from home and multi-location work arrangements prior to COVID (Ojala and Pyöriä 2018). While the technological is the same, it seems likely that countries and organizations that have already embraced a "flexicurity" policy (Wilthagen and Tros 2004) will be better adapted to exploit new remote work opportunities.

\section{Conclusion}

Alternative forms of work organization are made possible by new technologies that enable offshoring, outsourcing, and remote work, and can be viewed in a simple typology that combines configurations of these three non-traditional models. While various innovations have been prophesied to foretell a new equilibrium in the organization of work, we propose a model that focuses on how external shocks, the institutional environment, and limitations in practice influence the bargaining process over whether and how these will be implemented, leading to a revised social contract that stabilizes the workplace understanding of roles and responsibilities.

Just as offshoring and outsourcing ate away at the core employment of many organizations, remote work could have a similar effect in some contexts, although substantial limitations in practice and institutional barriers continue to influence these outcomes, as also suggested by the 
experience with outsourcing and offshoring. New technology both expands the potential scope of remote work and monitoring within the traditional workplace, and can provide opportunities for discontinuous change or for organizations to layer new practices atop existing traditional workplace arrangements.

The process of shifting work from on-premises to remote may involve 1) the growth of specialist firms with "globally distributed platform work" that is outsourced, offshore, and offpremises, and "virtual companies" that are offshore and are off-premises; 2) the transformation of the traditional workplace monitoring by layering platforms, remote work arrangements, and remote outsourcing agreements atop the existing employee base; 3) growing dissatisfaction from workers as needs and desires for greater flexibility and security grow; 4) growing dissatisfaction from employers and governments with the instability emerging from a lack of structure around remote work; and 5) calls for discontinuous or more layered changes in labor and employment relations policies as workers seek security, employers seek stable structures to manage and retain control over the remote workplace, and countries grapple with the implications of globally distributed platform work and virtual companies. A revised social contract will be needed to regulate these potential developments and enable a new equilibrium in the organization of work. 


\section{References}

Anner, Mark, Fischer-Daly, Matthew and Maffie, Michael. 2021. Fissured Employment and Network Bargaining: Emerging Employment Relations Dynamics in a Contingent World of Work. Industrial and Labor Relations Review, 74(3), pp. 680-714. doi: 10.1177/0019793920964180.

Antràs, Pol, \& Helpman, Elhanan. 2009. Contractual Frictions and Global Sourcing. In D. Marin \& T. H. Verdier, The Organization of Firms in a Global Economy pp. 9-54. Cambridge, MA: Harvard University Press.

Bacharach, Samuel B., \& Lawler, Edward J. 1980. Power and Politics in Organizations. San Francisco, CA: Jossey-Bass.

Barley, Stephen R. 2020. Work and Technological Change. Oxford, UK: Oxford University Press.

Barley, Stephen R., \& Kunda, Gideon. 2011. Gurus, Hired Guns, and Warm Bodies: Itinerant Experts in a Knowledge Economy. Princeton, NJ: Princeton University Press.

Bernstein, Ethan S. 2016. Making transparency transparent: The evolution of observation in management theory. Academy of Management Annals, 11(1): 217-266.

Blinder, Alan S. 2006. Offshoring: The next industrial revolution. Foreign Affairs, 852, 113128.

Bound, John, Khanna, Gaurav, \& Morales, Nicolas. 2018. Understanding the Economic Impact of the H- 1B Program on the United States. In G. H. Hanson, W. R. Kerr, \& S. Turner, High-Skilled Migration to the United States and Its Economic Consequences pp. 109176. Chicago, IL: University of Chicago Press. 
Briscoe, Forrest. 2007. From Iron Cage to Iron Shield? How Bureaucracy Enables Temporal Flexibility for Professional Service Workers. Organization Science, 182, 297-314. https://doi.org/10.1287/orsc.1060.0226

Bunyaratavej, Kraiwinee, Hahn, Eugene D., \& Doh, Jonathan P. 2007. International offshoring of services: A parity study. Journal of International Management, 131, 7-21.

Bureau of Labor Statistics. 2002. Work at Home In 2001. Accessed at https://www.bls.gov/news.release/history/homey_03012002.txt (June 2021).

Bureau of Labor Statistics. 2005. Work At Home Summary. Accessed at https://www.bls.gov/news.release/homey.nr0.htm (June 2021).

Bureau of Labor Statistics. 2018. Contingent and alternative employment arrangements.

Accessed at https://www.bls.gov/news.release/conemp.nr0.htm (June 2021).

Bureau of Labor Statistics. 2019. Job Flexibilities and Work Schedules - 2017-2018. Accessed at https://www.bls.gov/news.release/flex2.nr0.htm (June 2021).

Bureau of Labor Statistics. 2021. Effects of the coronavirus COVID-19 pandemic (CPS). Accessed at https://www.bls.gov/cps/effects-of-the-coronavirus-covid-19-pandemic.htm (June 2021).

Cascio, Wayne F. 2000. Managing a virtual workplace. Academy of Management Perspectives, 143, 81-90. https://doi.org/10.5465/ame.2000.4468068

Chamberlain, Neil W. 1951. Organized Labor and Management Control. The ANNALS of the American Academy of Political and Social Science, 2741, 152-160. https://doi.org/10.1177/000271625127400122

Chamberlain, Neil W. 1963. The Union Challenge to Management Control. ILR Review, 162, 184-192. https://doi.org/10.1177/001979396301600202 
Cole, Robert E. 1979. Work, Mobility, and Participation: A Comparative Study of American and Japanese Industry. Berkeley, CA: University of California Press.

Contractor, Farok J., Kumar, Vikas, Kundu, Sumit K., \& Pedersen, Torben. 2010.

Reconceptualizing the Firm in a World of Outsourcing and Offshoring: The

Organizational and Geographical Relocation of High-Value Company Functions. Journal

of Management Studies, 478, 1417-1433. https://doi.org/10.1111/j.1467-

$\underline{6486.2010 .00945 . x}$

Contractor, Farok J., \& Mudambi, Susan M. 2008. The influence of human capital investment on the exports of services and goods: An analysis of the top 25 services outsourcing countries. Management International Review, 484, 433-445.

https://doi.org/10.1007/s11575-008-0025-9

Cusumano, Michael A. 1991. Japan's Software Factories: A Challenge to U.S. Management. New York, NY: Oxford University Press USA.

Dey, Matthew, Frazis, Harley, Loewenstein, Mark A., \& Sun, Hugette. 2020. Workers ages 25 to 54 more likely to telework due to COVID-19 in February 2021. Monthly Labor Review. https://doi.org/10.21916/mlr.2020.14.

Dingel, Jonathan I., \& Neiman, Brent. 2020. How many jobs can be done at home? Journal of Public Economics, 189, 104235. https://doi.org/10.1016/j.jpubeco.2020.104235

Doellgast, Virginia, \& Benassi, Chiara. 2020. Collective bargaining. In Adrian Wilkinson, Jimmy Donaghey, Tony Dundon, \& Richard B. Freeman (Eds., Handbook of research on employee voice Second edition. Cheltenham, UK ; Northampton, MA, USA: Edward Elgar Publishing. 
Dore, Ronald P. 1973. British factory, Japanese factory: the origins of national diversity in industrial relations. Berkeley, CA: University of California Press.

Dossani, Rafiq, \& Kenney, Martin. 2007. The Next Wave of Globalization: Relocating Service Provision to India. World Development, 355, 772-791. https://doi.org/10.1016/j.worlddev.2006.09.014

Dube, Arindrajit, \& Kaplan, Ethan. 2010. Does Outsourcing Reduce Wages in the Low-Wage Service Occupations? Evidence from Janitors and Guards. ILR Review, 632, 287-306. https://doi.org/10.1177/001979391006300206

Eden, Lorraine. 2005. Went for Cost, Priced at Cost? An Economic Approach to the Transfer Pricing of Offshored Business Services SSRN Scholarly Paper ID 733823. Social Science Research Network. https://doi.org/10.2139/ssrn.733823

Erickson, Christopher L., Fisk, Catherine L., Milkman, Ruth, Mitchell, Daniel J. B., \& Wong, Kent. 2002. Justice for Janitors in Los Angeles: Lessons from Three Rounds of Negotiations. British Journal of Industrial Relations, 403, 543-567. https://doi.org/10.1111/1467-8543.00246

Erickson, Christopher L., \& Jacoby, Sanford M. 2003. The Effect of Employer Networks on Workplace Innovation and Training. ILR Review, 562, 203-223. https://doi.org/10.1177/001979390305600201

Erickson, Christopher L., \& Mitchell, Daniel J. B. 2007. Monopsony as a metaphor for the emerging post-union labour market. International Labour Review, 1463-4, 163-187. https://doi.org/10.1111/j.1564-913X.2007.00012.x

Freidson, Eliot. 1974. Professional Dominance: The Social Structure of Medical Care. Transaction Publishers. 
Green, Daryl D., \& Roberts, Gary E. 2010. Personnel Implications of Public Sector Virtual Organizations. Public Personnel Management, 391, 47-57.

https://doi.org/10.1177/009102601003900103

Hahn, Eugene D., Bunyaratavej, Kraiwinee, \& Doh, Jonathan P. 2011. Impacts of Risk and Service Type on Nearshore and Offshore Investment Location Decisions: An Empirical Approach. Management International Review, 513, 357-380.

Hätönen, Jussi, \& Eriksson, Taina. 2009. 30+ years of research and practice of outsourcing Exploring the past and anticipating the future. Journal of International Management, 152, 142-155. https://doi.org/10.1016/j.intman.2008.07.002

Jacoby, Sanford M. 2004. Employing Bureaucracy: Managers, Unions, and the Transformation of Work in the 20th Century, Revised Edition. Maywah, NJ: Lawrence Erlbaum Associates Press.

Jacoby, Sanford M. 2005. The Embedded Corporation: Corporate Governance and Employment Relations in Japan and the United States. Princeton, NJ: Princeton University Press.

Javalgi, Rajshekhar (Raj) G., Dixit, Ashutosh, \& Scherer, Robert F. 2009. Outsourcing to emerging markets: Theoretical perspectives and policy implications. Journal of International Management, 152, 156-168. https://doi.org/10.1016/j.intman.2008.08.001

Katz, Harry C. 1985. Shifting Gears: Changing Labor Relations in the U.S. Automobile Industry. Cambridge, MA: MIT Press.

Katz, Harry C. and Darbishire, Owen. 2018. Converging Divergences: Worldwide Changes in Employment Systems. Ithaca, NY: Cornell University Press.

Kellogg, Katherine C., Valentine, Melissa A., \& Christin, Angèle. 2020. Algorithms at work: The new contested terrain of control. Academy of Management Annals, 14(1), 366-410. 
Kelly, Erin L., \& Kalev, Alexandra. 2006. Managing flexible work arrangements in US organizations: Formalized discretion or 'a right to ask.' Socio-Economic Review, 43, 379-416. https://doi.org/10.1093/ser/mw1001

Kshetri, Nir. 2007. Institutional factors affecting offshore business process and information technology outsourcing. Journal of International Management, 131, 38-56. https://doi.org/10.1016/j.intman.2006.05.003

Kshetri, Nir, \& Dholakia, Nikhilesh. 2009. Professional and trade associations in a nascent and formative sector of a developing economy: A case study of the NASSCOM effect on the Indian offshoring industry. Journal of International Management, 152, 225-239. https://doi.org/10.1016/j.intman.2008.09.003

Lahiri, Somnath, \& Kedia, Ben L. 2011. Co-evolution of institutional and organizational factors in explaining offshore outsourcing. International Business Review, 203, 252-263. https://doi.org/10.1016/j.ibusrev.2011.01.005

Lakhani, Tashlin, Kuruvilla, Sarosh, \& Avgar, Ariel. 2013. From the Firm to the Network: Global Value Chains and Employment Relations Theory. British Journal of Industrial Relations, 513, 440-472. https://doi.org/10.1111/bjir.12015

Leamer, Edward E., \& Storper, Michael. 2014. The Economic Geography of the Internet Age. In J. Cantwell (Ed., Location of International Business Activities: Integrating Ideas from Research in International Business, Strategic Management and Economic Geography pp. 63-93. Palgrave Macmillan UK. https://doi.org/10.1057/9781137472311_4

Leonardi, P. M. and Bailey, D. E. 2008. Transformational technologies and the creation of new work practices: Making implicit knowledge explicit in task-based offshoring. MIS Quarterly 32: 411-36. 
Levy, Frank and Murnane, Richard J. 2012. The New Division of Labor: How Computers Are Creating the Next Job Market. Princeton, NJ: Princeton University Press.

Lewin, Arie Y, Massini, Silvia, \& Peeters, Carine. 2009. Why are companies offshoring innovation? The emerging global race for talent. Journal of International Business Studies, 406, 901-925. https://doi.org/10.1057/jibs.2008.92

Lewin, Arie Y., \& Volberda, Henk W. 2011. Co-evolution of global sourcing: The need to understand the underlying mechanisms of firm-decisions to offshore. International Business Review, 203, 241-251. https://doi.org/10.1016/j.ibusrev.2011.02.008

Lipsky, David B., Seeber, Ronald L., \& Fincher, Richard. 2003. Emerging Systems for Managing Workplace Conflict: Lessons from American Corporations for Managers and Dispute Resolution Professionals. Hoboken, NJ: John Wiley \& Sons.

Liu, Runjuan, Feils, Dorothee J, \& Scholnick, Barry. 2011. Why are different services outsourced to different countries? Journal of International Business Studies, 424, 558571. https://doi.org/10.1057/jibs.2010.61

Martínez-Noya, Andrea, \& García-Canal, Esteban. 2011. Technological capabilities and the decision to outsource/outsource offshore R\&D services. International Business Review, 203, 264-277. https://doi.org/10.1016/j.ibusrev.2011.01.008

Martínez-Noya, Andrea, \& García-Canal, Esteban. 2018. Location, shared suppliers and the innovation performance of R\&D outsourcing agreements. Industry and Innovation, 253, 308-332. https://doi.org/10.1080/13662716.2017.1329085

Martinez-Noya, Andrea, Garcia-Canal, Esteban, \& Guillen, Mauro F. 2012. International R\&D service outsourcing by technology-intensive firms: Whether and where? Journal of International Management, 181, 18-37. https://doi.org/10.1016/j.intman.2011.06.004 
Medcof, John W. 2001. Resource-based strategy and managerial power in networks of internationally dispersed technology units. Strategic Management Journal, 2211, 9991012. https://doi.org/10.1002/smj.192

Mihalache, Mashiho, \& Mihalache, Oli R. 2016. A Decisional Framework of Offshoring: Integrating Insights from 25 Years of Research to Provide Direction for Future*: A Decisional Framework of Offshoring. Decision Sciences, 476, 1103-1149. https://doi.org/10.1111/deci.12206

Mudambi, Ram, \& Venzin, Markus. 2010. The Strategic Nexus of Offshoring and Outsourcing Decisions. Journal of Management Studies, 478, 1510-1533. https://doi.org/10.1111/j.1467-6486.2010.00947.x

Norlander, Peter, Erickson, Christopher, Kuruvilla, Sarosh, \& Kannan-Narasimhan, Rangapriya. 2015. India's Outsourcing Industry and the Offshoring of Skilled Services Work: A Review Essay. E-Journal of International and Comparative Labour Studies, 41, Article 1. http://ejcls.adapt.it/index.php/ejcls_adapt/article/view/255

Norlander, Peter, Jukic, Nenad, Varma, Arup, \& Nestorov, Svetlozar. 2021. The effects of technological supervision on gig workers: Organizational control and motivation of Uber, taxi, and limousine drivers. The International Journal of Human Resource Management, 00, 1-25. https://doi.org/10.1080/09585192.2020.1867614

Norlander, Peter, \& Varma, Arup. 2019. H-1B and L-1 visa-sponsored guest workers in the USA: An analysis of the strategic impact of Indian and other firms. Thunderbird International Business Review, 614, 565-579. https://doi.org/10.1002/tie.22044 
Ojala, Satu, \& Pyöriä, Pasi. 2018. Mobile knowledge workers and traditional mobile workers: Assessing the prevalence of multi-locational work in Europe. Acta Sociologica, 614, 402-418. https://doi.org/10.1177/0001699317722593

Piore, Michael and Sabel, Charles. 1986. The Second Industrial Divide: Possibilities For Prosperity. New York, NY: Basic Books.

Ranganathan, Aruna, \& Benson, Alan. 2020. A numbers game: Quantification of work, autogamification, and worker productivity. American Sociological Review, 85(4), 573-609.

Rosenblat, Alex. 2018. Uberland: How algorithms are rewriting the rules of work. Oakland, CA: University of California Press.

Rugman, Alan M., \& Verbeke, Alain. 2001. Subsidiary-specific advantages in multinational enterprises. Strategic Management Journal, 223, 237-250. https://doi.org/10.1002/smj.153

Salancik, Gerald R. 1979. Interorganizational Dependence and Responsiveness to Affirmative Action: The Case of Women and Defense Contractors. Academy of Management Journal, 222, 375-394. https://doi.org/10.5465/255596

Saxenian, AnnaLee. 2007. The New Argonauts: Regional Advantage in a Global Economy. Cambridge, MA: Harvard University Press.

Schmeisser, Bjoern. 2013. A Systematic Review of Literature on Offshoring of Value Chain Activities. Journal of International Management, 194, 390-406. https://doi.org/10.1016/j.intman.2013.03.011

Stansbury, Anna, \& Summers, Lawrence H. 2020. The Declining Worker Power Hypothesis: An Explanation for the Recent Evolution of the American Economy. Brookings Papers on Economic Activity, 1-77. 
Stillman, Jessica. 2016. No Office, No Problem: 125 Companies Proving That Virtual Companies Can Thrive. Inc.com, April 14, 2016. (Accessed June 2021)

Streeck, Wolfgang. 2009. Re-Forming Capitalism: Institutional Change in the German Political Economy. Oxford, UK: OUP Oxford.

Tambe, Prasanna, \& Hitt, Lorin M. 2012a. Now IT's Personal: Offshoring and the Shifting Skill Composition of the U.S. Information Technology Workforce. Management Science, 584, 678-695. https://doi.org/10.1287/mnsc.1110.1445

Tambe, Prasanna, \& Hitt, Lorin M. 2012b. The Productivity of Information Technology Investments: New Evidence from IT Labor Data. Information Systems Research, 233part-1, 599-617. https://doi.org/10.1287/isre.1110.0398

Taskin, Laurent, \& Edwards, Paul. 2007. The possibilities and limits of telework in a bureaucratic environment: Lessons from the public sector. New Technology, Work and Employment, 223, 195-207. https://doi.org/10.1111/j.1468-005X.2007.00194.X

Taylor, C. Barr, Ruzek, Josef I., Fitzsimmons-Craft, Ellen E., Sadeh-Sharvit, Shiri, Topooco, Naira, Weissman, Ruth Striegel, Eisenberg, Daniel, Mohr, David, Graham, Andrea, Jacobi, Corinna, \& Oldenburg, Brian. 2020. Using Digital Technology to Reduce the Prevalence of Mental Health Disorders in Populations: Time for a New Approach. Journal of Medical Internet Research, 227, e17493. https://doi.org/10.2196/17493

Thelen, Kathleen. 2003. How Institutions Evolve: Insights from Comparative-Historical Analysis. In James Mahoney and Dietrich Rueschemeyer (Eds.), Comparative Historical Analysis in the Social Sciences, pp. 208-240. New York: Cambridge University Press.

Thelen, Kathleen. 2004. How Institutions Evolve: The Political Economy of Skills in Germany, Britain, the United States, and Japan. New York: Cambridge University Press. 
Thelen, Kathleen. 2009. Institutional Change in Advanced Political Economies. British Journal of Industrial Relations, 47(3), 471-498. https://doi.org/10.1111/j.14678543.2009.00746.x

Willcocks, Leslie, \& Griffiths, Catherine. 2010. The Crucial Role of Middle Management in Outsourcing. MIS Quarterly Executive, 93. https://aisel.aisnet.org/misqe/vol9/iss3/6 Wilmers, Nathan. 2018. Wage Stagnation and Buyer Power: How Buyer-Supplier Relations Affect U.S. Workers’ Wages, 1978 to 2014. American Sociological Review, 832, 213242. https://doi.org/10.1177/0003122418762441

Wilthagen, Ton, \& Tros, Frank. 2004. The concept of 'flexicurity': A new approach to regulating employment and labour markets. Transfer: European Review of Labour and Research, 102, 166-186. https://doi.org/10.1177/102425890401000204

Yu, Kyoung-Hee, \& Levy, Frank. 2010. Offshoring Professional Services: Institutions and Professional Control. British Journal of Industrial Relations, 484, 758-783. https://doi.org/10.1111/j.1467-8543.2010.00812.x

Zaheer, Srilata, Lamin, Anna, \& Subramani, Mani. 2009. Cluster capabilities or ethnic ties? Location choice by foreign and domestic entrants in the services offshoring industry in India. Journal of International Business Studies, 406, 944-968. https://doi.org/10.1057/jibs.2008.91 